$\begin{array}{ll}\text { Abstracta Iranica } & \begin{array}{l}\text { Abstracta Iranica } \\ \text { Revue bibliographique pour le domaine irano-aryen }\end{array} \\ & \text { Volume } \mathbf{2 8} \mid \mathbf{2 0 0 7} \\ & \text { Comptes rendus des publications de } \mathbf{2 0 0 5}\end{array}$

\title{
Le message de Hallâj l'Expatrié. Paris, Cerf, 2005,
} $422 \mathrm{p}$.

Pierre Lory

\section{(2) OpenEdition}

\section{Journals}

Édition électronique

URL : http://journals.openedition.org/abstractairanica/13152

DOI : 10.4000/abstractairanica.13152

ISSN : 1961-960X

Éditeur :

CNRS (UMR 7528 Mondes iraniens et indiens), Éditions de l'IFRI

\section{Édition imprimée}

Date de publication : 15 mai 2007

ISSN : 0240-8910

\section{Référence électronique}

Pierre Lory, « Le message de Hallâj l'Expatrié. Paris, Cerf, 2005, 422 p. », Abstracta Iranica [En ligne], Volume 28 | 2007, document 289, mis en ligne le 18 septembre 2007, consulté le 25 septembre 2020 URL : http://journals.openedition.org/abstractairanica/13152 ; DOI : https://doi.org/10.4000/ abstractairanica.13152

Ce document a été généré automatiquement le 25 septembre 2020.

Tous droits réservés 


\section{Le message de Hallâj l'Expatrié. Paris, Cerf, 2005, 422 p.}

\section{Pierre Lory}

L'A. a décidé de reprendre les travaux sur Ḩallāj là où Massignon les avait laissés, en y intégrant ce que la recherche et la réflexion ultérieure ont pu y ajouter. Après une substantielle introduction historique, il donne une nouvelle traduction du Dìvān, d'extraits des AHbār et d'autres citations, regroupées ici sous les titres « Hymnes et prières » et "Aphorismes et sentences"; enfin, des fameuse Revāyāt (ici : «Paroles prophétiques»). Le tout est accompagné d'une abondante annotation. Ce travail approfondi ne vient donc pas doubler celui de Massignon, mais apporter de nouveaux éclairages, une nouvelle sensibilité, et fournit de nombreuses trouvailles.

INDEX

Thèmes : 8 . Soufisme

\section{AUTEURS}

PIERRE LORY

EPHE - Paris 